\title{
Organocatalytic asymmetric fluorination of $\alpha$-chloroaldehydes involving kinetic resolution
}

\author{
Kazutaka Shibatomi ${ }^{*}$, Takuya Okimi, Yoshiyuki Abe, Akira Narayama, \\ Nami Nakamura and Seiji Iwasa
}

\author{
Full Research Paper \\ Address: \\ Department of Environmental and Life Sciences, Toyohashi University \\ of Technology, 1-1 Hibarigaoka, Tempaku-cho, Toyohashi 441-8580, \\ Japan \\ Email: \\ Kazutaka Shibatomi* - shiba@ens.tut.ac.jp \\ * Corresponding author \\ Keywords: \\ a-branched aldehyde; asymmetric catalysis; chlorination; fluorination; \\ organocatalyst; organo-fluorine
}

Open Access

\author{
Beilstein J. Org. Chem. 2014, 10, 323-331. \\ doi:10.3762/bjoc. 10.30 \\ Received: 25 October 2013 \\ Accepted: 03 January 2014 \\ Published: 04 February 2014 \\ This article is part of the Thematic Series "Organo-fluorine chemistry III". \\ Guest Editor: D. O'Hagan \\ (c) 2014 Shibatomi et al; licensee Beilstein-Institut. \\ License and terms: see end of document.
}

\begin{abstract}
In a previous study it was shown that the enantioselective $\alpha$-fluorination of racemic $\alpha$-chloroaldehydes with a chiral organocatalyst yielded the corresponding $\alpha$-chloro- $\alpha$-fluoroaldehydes with high enantioselectivity. It was also revealed that kinetic resolution of the starting aldehydes was involved in this asymmetric fluorination. This paper describes the determination of the absolute stereochemistry of a resulting $\alpha$-chloro- $\alpha$-fluoroaldehyde. Some information about the substrate scope and a possible reaction mechanism are also described which shed more light on the nature of this asymmetric fluorination reaction.
\end{abstract}

\section{Introduction}

Fluorinated organic molecules are of considerable interest in pharmaceutical and agricultural chemistry owing to the unique properties of the fluorine atom $[1,2]$. These compounds, especially with one or more fluorinated stereogenic center(s), are fascinating building blocks for new drug candidates. Organocatalytic $\alpha$-fluorination of aldehydes is known to be an efficient strategy for the enantioselective construction of fluorinated chiral carbon centers [3-6]; however, very few successful studies have been published on the fluorination of $\alpha$-branched aldehydes [7]. During the course of our study on the enantioselective construction of such fluorinated stereogenic centers, we developed a method for the enantioselective synthesis of $\alpha$-chloro- $\alpha$-fluoroaldehydes via the organocatalytic $\alpha$-fluorination of $\alpha$-alkyl- $\alpha$-chloroaldehydes, a type of $\alpha$-branched aldehyde, mediated by the Jørgensen-Hayashi catalyst 1 [8]. The reaction yielded the desired $\alpha$-chloro- $\alpha$-fluoroaldehydes with high enantioselectivity when the starting aldehyde was used in excess over $N$-fluorobenzenesulfonimide (NFSI) in the reaction. However, when an excess NFSI with respect to the starting aldehyde was used, poor asymmetric induction was observed. In this paper, we describe the determination of the absolute stereochemistry of a resulting $\alpha$-chloro- $\alpha$-fluoroaldehyde using this methodology and discuss the possible reaction mechanism that involves kinetic resolution. 


\section{Results and Discussion}

In our previous study [8], enantioselective fluorination of racemic 2-chloro-3-phenylpropanal (2a) was carried out with 3 equiv of NFSI in the presence of organocatalyst $(S)-\mathbf{1}$ to yield the corresponding $\alpha$-chloro- $\alpha$-fluoroaldehyde 3a in good conversion. Isolation of the product and determination of enantiomeric purity were performed after reduction to primary alcohol 4a because 3a was unstable to silica gel chromatography. The reaction afforded $4 \mathbf{a}$ with high enantioselectivity along with the monochloro alcohol 5a, whose enantiomeric purity was determined to be $37 \%$ ee (Scheme 1) [8]. These results suggested that kinetic resolution of the starting aldehydes was involved in this asymmetric fluorination.

To collect further information on the reaction mechanism, we sought to determine the absolute configuration of $4 \mathbf{a}$. Recently, we reported the enantioselective synthesis of $\alpha$-chloro- $\alpha$-fluoro$\beta$-keto esters via the sequential chlorination-fluorination of $\beta$-keto esters with the $\mathrm{Cu}(\mathrm{II})$ complex of SPYMOX [9], a spiro chiral oxazoline ligand developed by our research group [9-12] In that study, we succeeded in determining the absolute stereochemistry of the $\alpha$-chloro- $\alpha$-fluoro- $\beta$-keto ester 6 by the X-ray crystallographic analysis of its derivative 7 (Scheme 2). Here, our aim was to transform chlorofluoro ester 6 to $4 \mathbf{a}$ in order to compare its optical rotation with that of $\mathbf{4 a}$ derived from $\mathbf{2 a}$ in the presence of catalyst $(S)$-1. As shown in Scheme 3, $\beta$-keto ester 6 was converted via the Barton-McCombie deoxygenation [13] into a simple ester 10, which was then reduced to the primary alcohol 4a by treatment with $\mathrm{LiAlH}_{4}$. Comparison of the optical rotations and retention times on chiral HPLC clearly showed that the asymmetric fluorination of 2a catalyzed by $(S)-1$ yielded 4a having the $R$ configuration (Scheme 1).

An investigation of the substrate scope of the organocatalytic fluorination of $\alpha$-chloroaldehydes was performed as shown in Table 1. The reaction of $\mathbf{2 a}$ with 3 equiv of NFSI yielded $\mathbf{4 a}$ in $87 \%$ ee along with monochloro alcohol $5 \mathbf{a}$ in $37 \%$ ee (Table 1 , entry 2) as described above. On the other hand, the reaction with 2 equiv of NFSI against to 2 a showed poor enantioselectivity ( $31 \%$ ee, Table 1 , entry 1$)$. We also examined the reaction with 2 equiv of $\mathbf{2 a}$ based on NFSI. The reaction yielded 4a in $75 \%$ ee (lower ee than that in Table 1, entry 2), and the enantiomeric purity of the recovered 5a was increased to $52 \%$ ee (Table 1, entry 3 ). Similar trends were observed in the fluorination with some other substrates $\mathbf{2 b}-\mathbf{2 g}$ (Table 1, entries 4-14). These results strongly suggested that the high asym-

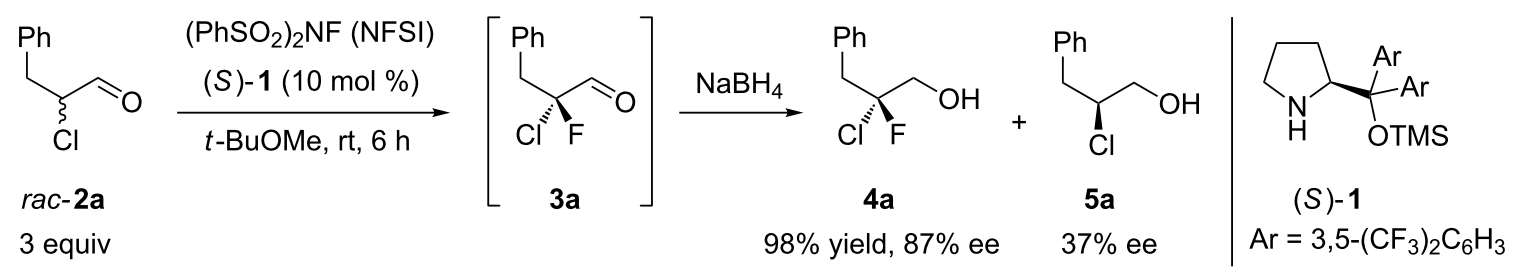

Scheme 1: Organocatalytic enantioselective fluorination of $\alpha$-chloroaldehyde 2a [8]<smiles>CC(C)[C@H]1CC[C@@H](C)C[C@H]1OC(=O)C(Cl)C(=O)c1ccccc1</smiles><smiles></smiles><smiles>CC1CC[C@H](OC(=O)C(F)(Cl)C(=O)c2ccccc2)C(C(C)C)C1</smiles>

6 $85 \%$ yield, $94 \%$ de<smiles>[3H]C(=O)O[C@H](c1ccccc1)C(F)(Cl)C(=O)O[C@@H]1C[C@H](C)CC[C@@H]1C(C)C</smiles>

$787 \%$ yield

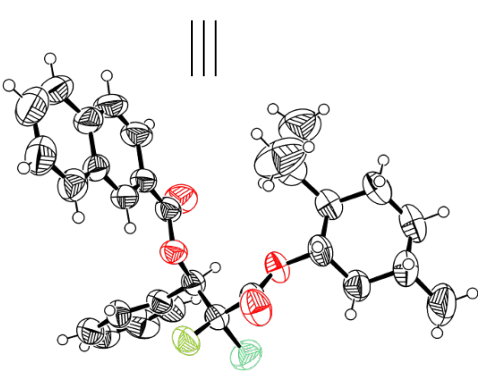




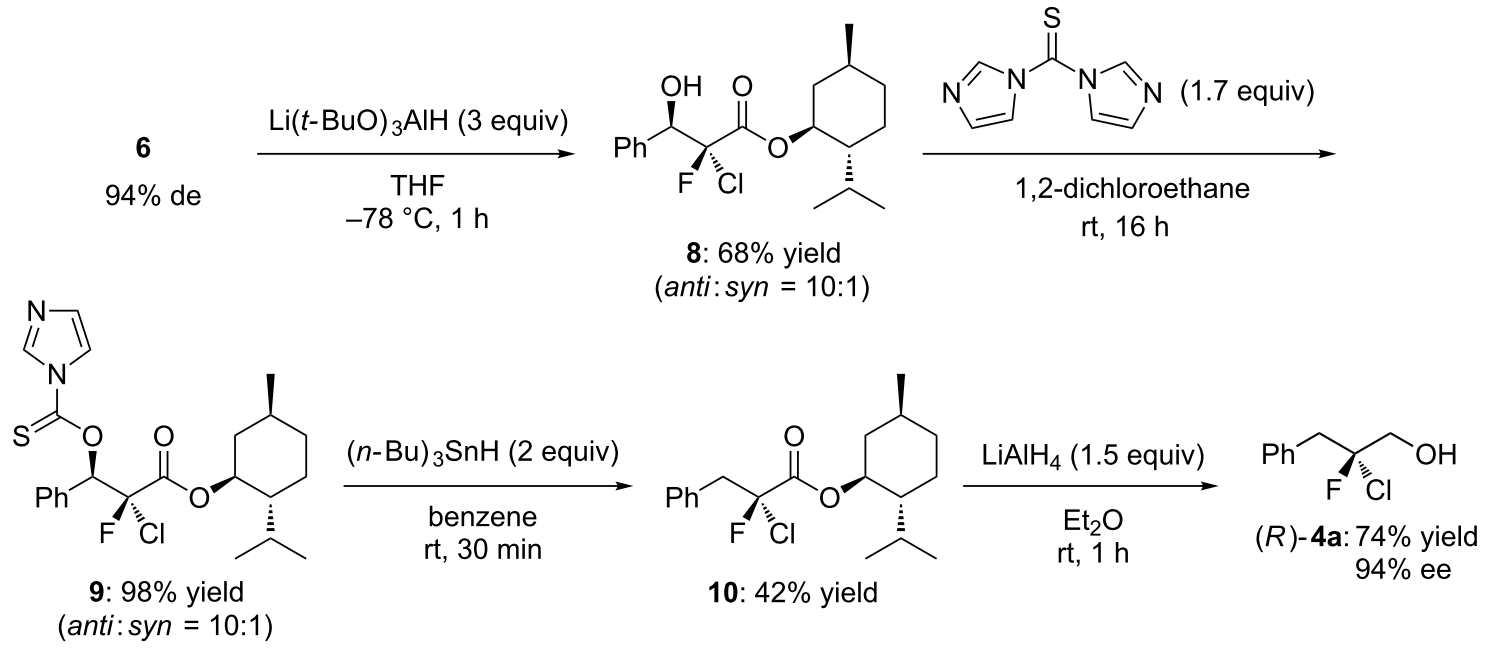

Scheme 3: Transformation of $\alpha$-chloro- $\alpha$-fluoro- $\beta$-keto ester 6 to chlorofluoro alcohol $4 a$.

Table 1: Enantioselective fluorination of a-chloroaldehydes. ${ }^{a}$



\begin{tabular}{|c|c|c|c|c|c|c|}
\hline entry & $\mathrm{R}$ & 2:NFSI & $t(\mathrm{~h})$ & $\%$ yield of $4^{b}$ & $\%$ ee of $4^{c}$ & $\%$ ee of $\mathbf{5}^{\mathrm{c}, \mathrm{d}}$ \\
\hline $1^{e}$ & $\mathrm{Bn}(\mathbf{2 a})$ & $1: 2$ & 11 & 78 & $31(R)$ & - \\
\hline $2^{e, f}$ & $\mathrm{Bn}$ & $3: 1$ & 6 & 98 & $87(R)$ & $37(S)$ \\
\hline 3 & $\mathrm{Bn}$ & $2: 1$ & 6 & 96 & $75(R)$ & $52(S)$ \\
\hline 4 & $n$-Hex (2b) & $1: 2$ & 11 & 82 & 31 & - \\
\hline $5^{e, f}$ & $n$-Hex & $3: 1$ & 10 & 97 & 80 & $35(S)$ \\
\hline 6 & $n$-Hex & $2: 1$ & 19 & 92 & 68 & $49(S)$ \\
\hline 7 & $-\left(\mathrm{CH}_{2}\right)_{3} \mathrm{OCH}_{2} \mathrm{OCH}_{3}(2 \mathrm{c})$ & $1: 2$ & 19 & 83 & 23 & - \\
\hline $8^{f}$ & $-\left(\mathrm{CH}_{2}\right)_{3} \mathrm{OCH}_{2} \mathrm{OCH}_{3}$ & $3: 1$ & 10 & 90 & 78 & $33(S)$ \\
\hline $9^{f}$ & $-\left(\mathrm{CH}_{2}\right)_{3} \mathrm{CO}_{2} \mathrm{Et}(\mathbf{2 d})$ & $3: 1$ & 4 & 90 & 80 & 20 \\
\hline $10^{g}$ & $c-H e x(2 e)$ & $1: 2$ & 48 & 88 & 42 & - \\
\hline $11^{\mathrm{g}}$ & $c-H e x$ & $3: 1$ & 24 & 92 & 96 & 15 \\
\hline 12 & $\mathrm{Ph}(\mathbf{2 f})$ & $1: 2$ & 12 & 61 & 72 & - \\
\hline $13^{e, f}$ & $\mathrm{Ph}$ & $3: 1$ & 10 & 82 & 90 & 5 \\
\hline $14^{e, g}$ & $t$-Bu $(2 \mathrm{~g})$ & $3: 1$ & 30 & 87 & 99 & 29 \\
\hline
\end{tabular}

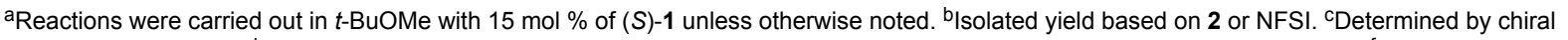

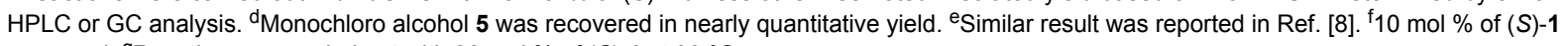
was used. gReaction was carried out with $30 \mathrm{~mol} \%$ of $(S)-1$ at $30{ }^{\circ} \mathrm{C}$.

metric induction in this fluorination requires not only control of enantiofacial selection during electrophilic fluorination of the enamine intermediates, but also a high level of kinetic resolution of the starting aldehydes.

From these results, we proposed a reaction mechanism for the fluorination of $\alpha$-chloroaldehydes, as shown in Scheme 4. Cata- lyst $(S)$-1 reacts with $(R)-\mathbf{2 a}$ to form iminium intermediate I, which undergoes deprotonation from the side opposite to the bulky substituent $\mathrm{X}\left(\mathrm{X}=\mathrm{CAr}_{2} \mathrm{OTMS}\right)$ of the pyrrolidine ring to afford enamine intermediate $(Z)-\mathbf{1 1}$ (path A). Then, NFSI attacks (Z)-11 from the side opposite to $\mathrm{X}$ to yield $(R)-\mathbf{3 a}$. Although deprotonation may also occur from the same side as $\mathrm{X}$ to give $(E)-\mathbf{1 1}$ (path B), the reaction through path $\mathrm{B}$ is consid- 


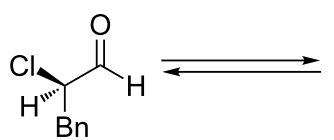

(R)-2a

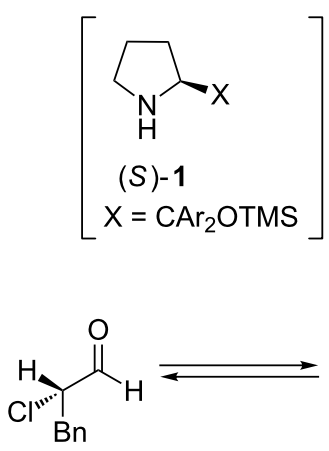

(S)-2a
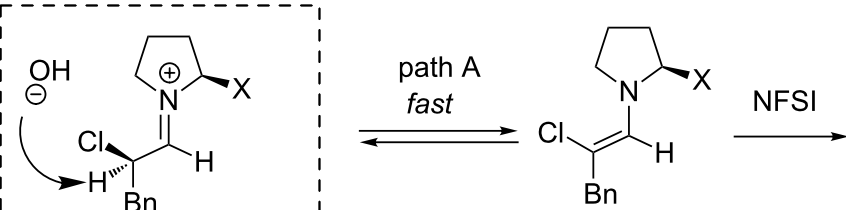

(Z)-11<smiles>O=CC(F)(F)Br</smiles>

$(R)-3 a$<smiles>[X]C1CCCN1C(/C=C\C(=O)O)=C(/Cl)CCC</smiles><smiles>[X]C1CCCN1C(/C=C\C#C)=C(\Cl)Cc1ccco1</smiles>

(Z)-11

$(R)-3 a$

intermediate I

Scheme 4: Proposed reaction mechanism.

ered to be very slow because the steric repulsion between the counter anion $\left(\mathrm{OH}^{-}\right)$and $\mathrm{X}$ would prevent deprotonation. Further, the resulting $(E)-\mathbf{1 1}$ would be a thermodynamically unfavorable product because of steric repulsion between the methylene group on the pyrrolidine ring and the benzyl substituent on 2a. Alternatively, $(S)$-2a reacts with $(S)$-1 to form iminium intermediate II, which also undergoes deprotonation to form $(E)$ - or $(Z)$-11. In these cases, deprotonation from the side opposite to $\mathrm{X}$ (path $\mathrm{C}$ ) is considered to be slow because the resulting $(E)-\mathbf{1 1}$ is a thermodynamically unfavorable form, as described above, and deprotonation from the same side as $\mathrm{X}$ (path D) is also slow because of steric repulsion between the counter anion $\left(\mathrm{OH}^{-}\right)$and $\mathrm{X}$. Thus, it is difficult to control the geometry of enamine intermediate 11 when starting from $(S)$ 2a, and hence, the enantioselectivity of the fluorination is significantly decreased because the fluorination occurs from the side opposite to X, regardless of the geometry of 11. For these reasons, high enantioselectivity was observed when $\mathbf{2 a}$ was employed in excess in the reaction, whereas an excess of NFSI led to poor asymmetric induction. In the former reaction, the major enantiomer of the recovered $\mathbf{5 a}$ was the $S$-form (Table 1, entries 2 and 3). This result also supports the proposed mechanism.

To test the proposed reaction mechanism, we carried out the fluorination of enantioenriched 2a (61\% ee, $R$ favored) with 2 equiv of NFSI in the presence of each enantiomer of catalyst 1. As expected from the mechanism, good enantioselectivity was observed when $(S)-\mathbf{1}$ was employed in the reaction, whereas the reaction proceeded more slowly to yield 4a with poor enantioselectivity in the presence of $(R)-\mathbf{1}$ (Scheme 5).

Finally, we were curious to know whether a similar kinetic resolution would be observed in the fluorination of $\alpha, \alpha$-dialkylaldehydes. We examined the fluorination of racemic $\alpha, \alpha-$ dialkylaldehyde $\mathbf{1 2}$ in the presence of catalyst 1 (Scheme 6). 


\begin{tabular}{|c|c|c|c|c|c|}
\hline$\overbrace{}^{-} \overbrace{0}$ & + & NFSI & $(S)-1(15 \mathrm{~mol} \%)$ & $\mathrm{NaBH}_{4}$ & 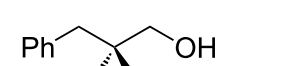 \\
\hline Cl & & 2 equiv & $t$-BuOMe, rt, $11 \mathrm{~h}$ & & \\
\hline 2a & & & & & $4 a$ \\
\hline $61 \%$ ee $(R)$ & & & & & $94 \%$ yield, $73 \%$ ee $(R)$ \\
\hline & + & ESI & $(R)-1(15 \mathrm{~mol} \%)$ & $\mathrm{NaBH}_{4}$ & \\
\hline $61 \%$ ee $(R)$ & & 2 equiv & $t$-BuOMe, rt, $36 \mathrm{~h}$ & & $94 \%$ yield, $22 \%$ ee $(R)$ \\
\hline
\end{tabular}
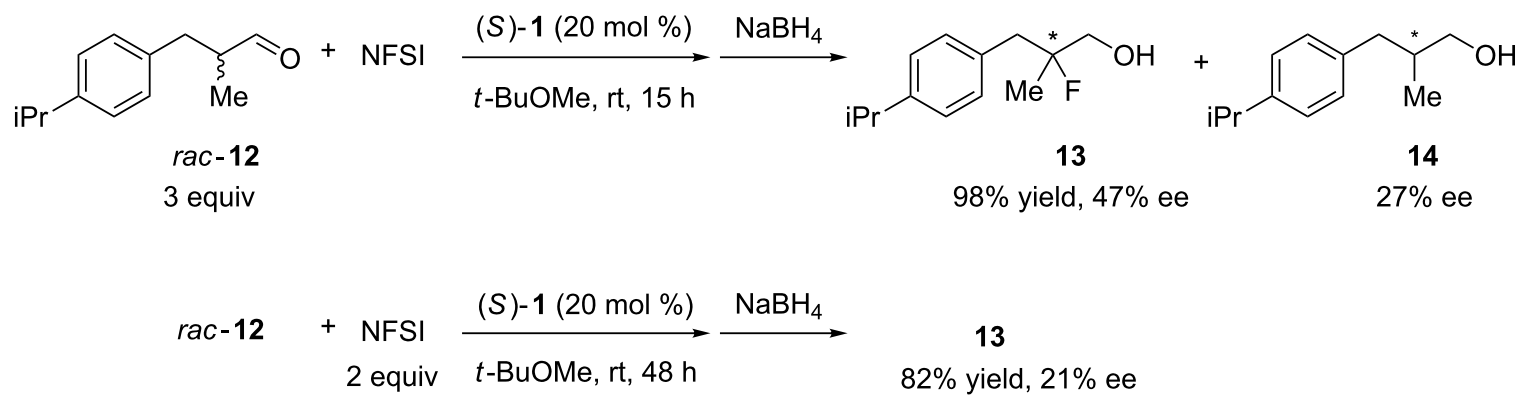

Scheme 6: Enantioselective fluorination of a-branched aldehyde 12.

The reaction with 3 equiv of $\mathrm{rac}-\mathbf{1 2}$ based on NFSI afforded the corresponding product $\mathbf{1 3}$ in higher enantioselectivity than that obtained in the reaction with 2 equiv of NFSI, along with $27 \%$ ee of 14; however the enantiomeric excess of 13 was not sufficiently high ( $47 \%$ ee). These results suggested that the reaction proceeded by a similar mechanism as shown in Scheme 4.

\section{Conclusion}

In conclusion, we succeeded in the highly enantioselective fluorination of $\alpha$-chloroaldehydes to afford $\alpha$-chloro- $\alpha$-fluoroaldehydes mediated by chiral organocatalyst 1 . It was revealed that kinetic resolution of the racemic $\alpha$-chloroaldehydes occurred during this fluorination reaction, which played an important role in the asymmetric induction.

\section{Experimental}

Experiments involving moisture- and/or air-sensitive compounds were performed in oven-dried flasks under an atmosphere of dry argon. All reactions were magnetically stirred and monitored by thin-layer chromatography (TLC) using precoated silica gel plates with $\mathrm{F}_{254}$ indicator. Visualization was accomplished with UV light (254 nm), or phosphomolybdic acid, potassium permanganate, or anisaldehyde staining.
Column chromatography was performed over silica gel (40-100 $\mu \mathrm{m}) .{ }^{1} \mathrm{H},{ }^{13} \mathrm{C}$, and ${ }^{19} \mathrm{~F}$ NMR spectra were acquired on a JEOL JNM-ECX500 spectrometer. Chemical shift values $(\delta)$ are reported in ppm $\left({ }^{1} \mathrm{H}: \delta 0.00\right.$ for tetramethylsilane; ${ }^{19} \mathrm{~F}: \delta$ 0.00 for trichlorofluoromethane; ${ }^{13} \mathrm{C}: \delta 77.0$ for residual chloroform). IR spectra were measured on a JASCO FT/IR-230 spectrometer. Elemental analysis was performed with a Yanaco CHN CORDER MT-6. High-performance liquid chromatography (HPLC) analyses were performed with a JASCO PU-1586 with a UV-1575 UV-vis detector using a chiral column. GC analysis was performed with a Shimadzu model 2014 instrument. Optical rotations were measured on a JASCO $\mathrm{P}-1030$ polarimeter.

$\alpha$-Chloro aldehydes 2 were prepared with $N$-chlorosuccinimide in the presence of organocatalyst according to the procedure reported by Jørgensen [14] and were distilled before use. Racemic forms were synthesized with DL-proline catalyst, and optically active $\mathbf{2 a}$ was synthesized with L-prolinamide catayst, whose enantiopurity was slightly decreased during the distillation.

We confirmed that the optical purity of fluorinated products 4 did not change even after chromatographic purification using 
achiral silica gel and subsequent solvent evaporation. Therefore, we concluded that the enantiomers did not undergo self-disproportionation during the purification process [15-19].

\section{Transformation of $\mathbf{6}$ to $(R)-\mathbf{4 a}$}

Compound $\mathbf{8}$ was synthesized from $\mathbf{6}(94 \% \mathrm{de})$ according to the procedure reported in [9]. A flame-dried flask under argon was charged with 8 (anti/syn $=10: 1,0.35 \mathrm{mmol})$ and 1,2dichloroethane (2 mL). 1,1'-Thiocarbonyldiimidazole $(0.6 \mathrm{mmol})$ was added to this solution, and the mixture was stirred for $16 \mathrm{~h}$ at ambient temperature. The mixture was quenched by adding saturated aqueous $\mathrm{NaHCO}_{3}$ and extracted with $\mathrm{CH}_{2} \mathrm{Cl}_{2}$. The organic layer was dried over $\mathrm{Na}_{2} \mathrm{SO}_{4}$ and concentrated under reduced pressure. The crude mixture was purified by silica gel column chromatography (1:1 hexane/ $\left.\mathrm{Et}_{2} \mathrm{O}\right)$ to give 9 in $98 \%$ yield (anti/syn $\left.=10: 1\right)$.

9: ${ }^{1} \mathrm{H}$ NMR $\left(400 \mathrm{MHz}, \mathrm{CDCl}_{3}\right) \delta 8.33(\mathrm{~s}, 1 \mathrm{H}), 7.83-7.72(\mathrm{~m}$, $6 \mathrm{H}), 7.06(\mathrm{~s}, 1 \mathrm{H}), 6.74(\mathrm{~d}, J=21.6 \mathrm{~Hz}, 1 \mathrm{H}), 4.87(\mathrm{td}, J=10.8$, $4.4 \mathrm{~Hz}, 1 \mathrm{H}), 2.01-1.94(\mathrm{~m}, 1 \mathrm{H}), 1.74-1.56(\mathrm{~m}, 4 \mathrm{H}), 1.55-1.36$ (m, 2H), 1.18-0.96 (m, 2H), $0.92(\mathrm{~d}, J=6.4 \mathrm{~Hz}, 3 \mathrm{H}), 0.74(\mathrm{~d}, J$ $=7.2 \mathrm{~Hz}, 3 \mathrm{H}), 0.52(\mathrm{~d}, J=7.2 \mathrm{~Hz}, 3 \mathrm{H}) ;{ }^{13} \mathrm{C} \mathrm{NMR}(100 \mathrm{MHz}$, $\left.\mathrm{CDCl}_{3}\right) \delta 180.6,163.6(\mathrm{~d}, J=29.4 \mathrm{~Hz}), 137.1,131.4,130.3$, $129.9,129.8,128.8,128.6,117.8,103.3(\mathrm{~d}, J=262.8 \mathrm{~Hz}), 84.5$ (d, $J=19.8 \mathrm{~Hz}), 78.8,46.8,40.1,33.9,31.5,26.2,22.8,22.0$, 20.7, 15.2; ${ }^{19} \mathrm{~F}$ NMR (376 MHz, $\left.\mathrm{CDCl}_{3}\right) \delta-132.1$ (d, $J=21.4$ $\mathrm{Hz}$; FTIR (neat) $v_{\max }: 2955,1762,1464,1395,1288,1212$, $1102,992,952,742,475 \mathrm{~cm}^{-1}$; anal calcd (\%) for $\mathrm{C}_{23} \mathrm{H}_{28} \mathrm{ClFN}_{2} \mathrm{O}_{3} \mathrm{~S}$ : C, 59.15; H, 6.04; N, 6.00; found: C, 59.18; $\mathrm{H}, 5.96$; N, 6.40 .

A flame-dried flask under argon was charged with 9 $(0.22 \mathrm{mmol})$ and benzene $(3.6 \mathrm{~mL})$. Tributyltin hydride $(0.45 \mathrm{mmol})$ was added to this solution, and the mixture was stirred for $30 \mathrm{~min}$ at room temperature. The solvent was removed under reduced pressure and the crude mixture was purified by silica gel column chromatography (5:1 hexane/ $\mathrm{CH}_{2} \mathrm{Cl}_{2}$ ) to give $\mathbf{1 0}$ in $42 \%$ yield.

10: ${ }^{1} \mathrm{H}$ NMR $\left(400 \mathrm{MHz}, \mathrm{CDCl}_{3}\right) \delta 7.35-7.25(\mathrm{~m}, 5 \mathrm{H}), 4.74(\mathrm{td}$, $J=10.8,4.4 \mathrm{~Hz}, 1 \mathrm{H}), 3.65(\mathrm{~d}, J=6.8 \mathrm{~Hz}, 1 \mathrm{H}), 3.59(\mathrm{~d}, J=3.2$ $\mathrm{Hz}, 1 \mathrm{H}), 1.85-1.76(\mathrm{~m}, 2 \mathrm{H}), 1.72-1.63(\mathrm{~m}, 2 \mathrm{H}), 1.50-1.41(\mathrm{~m}$, $2 \mathrm{H}), 1.37-1.19(\mathrm{~m}, 1 \mathrm{H}), 1.09-0.98(\mathrm{~m}, 1 \mathrm{H}), 0.95-0.91(\mathrm{~m}, 1 \mathrm{H})$, $0.89(\mathrm{~d}, J=2.4 \mathrm{~Hz}, 3 \mathrm{H}), 0.87(\mathrm{dd}, J=3.2 \mathrm{~Hz}, 3 \mathrm{H}), 0.74(\mathrm{dd}, J$ $=7.2 \mathrm{~Hz}, 3 \mathrm{H}) ;{ }^{13} \mathrm{C} \mathrm{NMR}\left(100 \mathrm{MHz}, \mathrm{CDCl}_{3}\right) \delta 165.3(\mathrm{~d}, J=$ $27.4 \mathrm{~Hz}), 132.3,130.7,130.6,128.5,127.9,106.1$ (d, $J=257.9$ Hz), 77.9, 46.8, 40.0, 34.0, 31.4, 26.1, 23.3, 22.0, 20.8, 16.1; ${ }^{19} \mathrm{~F}$ NMR $\left(376 \mathrm{MHz}, \mathrm{CDCl}_{3}\right) \delta-116.6(\mathrm{dd}, J=22.9,19.6 \mathrm{~Hz})$; FTIR (neat) $v_{\max }: 2954,1754,1458,1282,1216,1145,1043$, 952, 704, 624, $471 \mathrm{~cm}^{-1}$; anal calcd (\%) for $\mathrm{C}_{19} \mathrm{H}_{26} \mathrm{ClFO}_{2}: \mathrm{C}$, 66.95; H, 7.69; found: C, 67.02; H, 7.96.
A flame-dried flask under argon was charged with $\mathbf{1 0}$ $(0.07 \mathrm{mmol})$ and $\mathrm{Et}_{2} \mathrm{O}(0.2 \mathrm{~mL}) . \mathrm{LiAlH}_{4}(0.11 \mathrm{mmol})$ was added to this solution at $-78^{\circ} \mathrm{C}$, and the mixture was stirred for $1 \mathrm{~h}$ at room temperature. The reaction mixture was quenched with saturated aqueous $\mathrm{NH}_{4} \mathrm{Cl}$ and the mixture was extracted with $\mathrm{Et}_{2} \mathrm{O}$. The organic layer was dried over $\mathrm{Na}_{2} \mathrm{SO}_{4}$ and concentrated under reduced pressure. The crude mixture was purified by silica gel column chromatography (5:1 hexane/ EtOAc) to give $(R)-\mathbf{4 a}$ in $74 \%$ yield, with an enantiomeric purity of $94 \%$ ee.

4a: $[\alpha]_{\mathrm{D}}=-2.8\left(\right.$ c 1.5, $\left.\mathrm{CHCl}_{3}\right)$. HPLC (99:1 hexane/2-propanol; $1 \mathrm{~mL} / \mathrm{min}$; using a CHIRALPAK IC column $(0.46 \mathrm{~cm} \varnothing \times$ $25 \mathrm{~cm}$ )): $11.4 \mathrm{~min}$ (major) and $11.9 \mathrm{~min}$ (minor). These analytical data were identical to those of $\mathbf{4 a}$ synthesized from $\mathbf{2 a}$ with (S)-1.

\section{General procedure for the asymmetric fluorin- ation of $\alpha$-chloroaldehydes 2}

To a solution of $\alpha$-chloroaldehyde $2(1.5 \mathrm{mmol})$ in $t$-BuOMe $(2 \mathrm{~mL})$ was added catalyst $1(0.05 \mathrm{mmol})$ and NFSI $(0.5 \mathrm{mmol})$. The reaction mixture was stirred at room temperature for the time given in Table 1 and then poured into $\mathrm{MeOH} / \mathrm{CH}_{2} \mathrm{Cl}_{2}$ (1:4, $5 \mathrm{~mL})$ at $0{ }^{\circ} \mathrm{C}$. To this solution, $\mathrm{NaBH}_{4}(5 \mathrm{mmol})$ was added, and the mixture was stirred at room temperature for $1 \mathrm{~h}$. The reaction was quenched with saturated aqueous $\mathrm{NH}_{4} \mathrm{Cl}$, and the mixture was extracted with $\mathrm{Et}_{2} \mathrm{O}$. The organic layer was dried over $\mathrm{Na}_{2} \mathrm{SO}_{4}$, concentrated, and chromatographed on silica gel to give $\mathbf{4}$, along with monochloro alcohol $\mathbf{5}$.

The results of all spectroscopic analyses of compounds $\mathbf{4 a}, \mathbf{4 b}$, $\mathbf{4 f}, \mathbf{4 g}$, and 5a-5f were identical to those described in our previous report [8] and in references [20,21]. Absolute configuration of $\mathbf{5 a}-\mathbf{5} \mathbf{c}$ was confirmed by comparing their optical rotation to that reported in the above-mentioned literature [20].

(R)-2-Chloro-2-fluoro-3-phenylpropan-1-ol (4a, 87\% ee): ${ }^{1} \mathrm{H}$ NMR $\left(500 \mathrm{MHz}, \mathrm{CDCl}_{3}\right) \delta$ 7.35-7.30 (m, 5H), 3.88-3.71 (m, 2H), $3.46(\mathrm{dd}, J=32.3,15.0 \mathrm{~Hz}, 2 \mathrm{H}), 2.15(\mathrm{br}, 1 \mathrm{H})$; ${ }^{13} \mathrm{C} \mathrm{NMR}\left(125 \mathrm{MHz}, \mathrm{CDCl}_{3}\right) \delta 133.3(\mathrm{~d}, J=3.8 \mathrm{~Hz}), 130.7$, 128.4, 127.6, $114.8(\mathrm{~d}, J=247 \mathrm{~Hz}), 67.2(\mathrm{~d}, J=26.4 \mathrm{~Hz}), 44.6$ $(\mathrm{d}, J=21.4 \mathrm{~Hz}) ;{ }^{19} \mathrm{~F} \mathrm{NMR}\left(470 \mathrm{MHz}, \mathrm{CDCl}_{3}\right) \delta-114.2(\mathrm{~m})$; $[\alpha]_{\mathrm{D}}=-2.7\left(c 1.5, \mathrm{CHCl}_{3}\right)$. The enantiopurity was determined by HPLC (99:1 hexane/2-propanol; $1 \mathrm{~mL} / \mathrm{min}$; using a CHIRALPAK IC column $(0.46 \mathrm{~cm} \varnothing \times 25 \mathrm{~cm})): 11.4 \mathrm{~min}$ (major) and $11.9 \mathrm{~min}$ (minor).

2-Chloro-2-fluorooctan-1-ol (4b, 80\% ee): ${ }^{1} \mathrm{H}$ NMR $(500$ $\left.\mathrm{MHz}, \mathrm{CDCl}_{3}\right) \delta 3.91-3.78(\mathrm{~m}, 2 \mathrm{H}), 2.14-2.05(\mathrm{~m}, 3 \mathrm{H})$, $1.59-1.54$ (m, 2H), 1.37-1.29 (m, 6H), 0.90 (t, $J=7.0 \mathrm{~Hz}, 3 \mathrm{H})$; 
${ }^{13} \mathrm{C}$ NMR (125 MHz, $\left.\mathrm{CDCl}_{3}\right) \delta 116.1(\mathrm{~d}, J=245 \mathrm{~Hz}), 68.3(\mathrm{~d}$, $J=26.4 \mathrm{~Hz}), 38.5(\mathrm{~d}, J=21.3 \mathrm{~Hz}), 31.5,28.9,23.3$ (d, $J=3.8$ $\mathrm{Hz}), 22.5,14.0 ;{ }^{19} \mathrm{~F} \mathrm{NMR}\left(470 \mathrm{MHz}, \mathrm{CDCl}_{3}\right) \delta-113.9$ (br); $[\alpha]_{\mathrm{D}}=+2.0\left(c 0.5, \mathrm{CHCl}_{3}\right)$. The enantiopurity was determined by GC $\left(100-150{ }^{\circ} \mathrm{C}, 3{ }^{\circ} \mathrm{C} / \mathrm{min}\right.$; using a Chiral DEX B-DM column): $12.4 \mathrm{~min}$ (major) and $13.3 \mathrm{~min}$ (minor).

2-Chloro-2-fluoro-5-(methoxymethoxy)pentan-1-ol (4c, 78\% ee): ${ }^{1} \mathrm{H}$ NMR $\left(500 \mathrm{MHz}, \mathrm{CDCl}_{3}\right) \delta 4.63(\mathrm{~s}, 2 \mathrm{H}), 3.99-3.79(\mathrm{~m}$, $2 \mathrm{H}), 3.66-3.55(\mathrm{~m}, 2 \mathrm{H}), 3.37(\mathrm{~s}, 3 \mathrm{H}), 2.40-2.12(\mathrm{~m}, 3 \mathrm{H})$, 2.01-1.82 (m, 2H); ${ }^{13} \mathrm{C}$ NMR (125 MHz, $\left.\mathrm{CDCl}_{3}\right) \delta 115.8(\mathrm{~d}, J$ $=245 \mathrm{~Hz}), 96.4,68.4(\mathrm{~d}, J=26.4 \mathrm{~Hz}), 66.8,55.3,35.4(\mathrm{~d}, J=$ $21.6 \mathrm{~Hz}), 23.9(\mathrm{~d}, J=4.8 \mathrm{~Hz}) ;{ }^{19} \mathrm{~F} \mathrm{NMR}\left(470 \mathrm{MHz}, \mathrm{CDCl}_{3}\right) \delta$ $-114.3(\mathrm{~m}) ;[\alpha]_{\mathrm{D}}^{22}=+4.6\left(c 0.16, \mathrm{CHCl}_{3}\right)$; anal calcd $(\%)$ for $\mathrm{C}_{7} \mathrm{H}_{14} \mathrm{ClFO}_{3}$ : C, 41.91; H, 7.03; Cl, 17.67; F, 9.47; O, 23.92; found: $\mathrm{C}, 44.91 ; \mathrm{H}, 7.51$. The enantiopurity was determined after conversion into the corresponding 2-naphthoate $\mathbf{1 5 c}$.

A flame-dried flask under argon was charged with $\mathbf{4 c}$ $(0.10 \mathrm{mmol})$ and $\mathrm{CH}_{2} \mathrm{Cl}_{2}(1.0 \mathrm{~mL})$. Triethylamine $(0.20 \mathrm{mmol})$, 2-naphthoyl chloride $(0.15 \mathrm{mmol})$, and 4-dimethylaminopyridine $(0.01 \mathrm{mmol})$ were added to this solution, and the mixture was stirred for $2 \mathrm{~h}$ at $0{ }^{\circ} \mathrm{C}$. The mixture was diluted by saturated aqueous $\mathrm{NaHCO}_{3}$, and extracted with $\mathrm{CH}_{2} \mathrm{Cl}_{2}$. The organic layer was dried over $\mathrm{Na}_{2} \mathrm{SO}_{4}$ and concentrated under reduced pressure. The crude mixture was purified by silica gel column chromatography (hexane/ethyl acetate $5: 1$ ) to give the desired 2-naphthoate $\mathbf{1 5 c}$ in $82 \%$ yield.

2-Chloro-2-fluoro-5-(methoxymethoxy)pentyl 2-naphthoate (15c, 78\% ee): ${ }^{1} \mathrm{H}$ NMR (400 MHz, $\left.\mathrm{CDCl}_{3}\right) \delta 8.65(\mathrm{~s}, 1 \mathrm{H})$, $8.08(\mathrm{~d}, J=10.4 \mathrm{~Hz}, 1 \mathrm{H}), 7.98(\mathrm{~d}, J=8.4 \mathrm{~Hz}, 1 \mathrm{H}), 7.93-7.86$ (m, 2H), 7.67-7.53 (m, 2H), 4.83-4.66 (m, 2H), $4.61(\mathrm{~s}, 2 \mathrm{H})$, $3.62(\mathrm{t}, J=5.80 \mathrm{~Hz}, 2 \mathrm{H}), 3.34(\mathrm{~s}, 3 \mathrm{H}), 2.49-2.19(\mathrm{~m}, 2 \mathrm{H})$, 2.11-1.88 (m, 2H); ${ }^{13} \mathrm{C} \mathrm{NMR}\left(100 \mathrm{MHz}, \mathrm{CDCl}_{3}\right) \delta 165.6$, 135.8, 132.4, 131.6, 129.4, 128.6, 128.4, 127.8, 126.8, 126.3, $125.2,112.8(\mathrm{~d}, J=247 \mathrm{~Hz}), 96.4,68.1(\mathrm{~d}, J=26.8 \mathrm{~Hz}), 66.6$, $55.2,36.2(\mathrm{~d}, J=22.0 \mathrm{~Hz}), 23.9(\mathrm{~d}, J=3.83 \mathrm{~Hz}) ;{ }^{19} \mathrm{~F}$ NMR $\left(470 \mathrm{MHz}, \mathrm{CDCl}_{3}\right) \delta-111.7(\mathrm{~m}) ;[\alpha]_{\mathrm{D}}{ }^{22}=+7.5(c 0.36$, $\mathrm{CHCl}_{3}$ ); anal calcd (\%) for $\mathrm{C}_{18} \mathrm{H}_{20} \mathrm{ClFO}_{4}: \mathrm{C}, 60.93 ; \mathrm{H}, 5.68$; $\mathrm{Cl}, 9.99$; F, 5.35; O, 18.04; found: C, 60.95; H, 5.85. The enantiopurity was determined by HPLC (50:1 hexane/2-propanol; $0.5 \mathrm{~mL} / \mathrm{min}$; using a CHIRALPAK ID column $(0.46 \mathrm{~cm} \varnothing \times$ $25 \mathrm{~cm}$ )): $25.1 \mathrm{~min}$ (major) and $30.5 \mathrm{~min}$ (minor).

Ethyl 5-chloro-5-fluoro-6-hydroxyhexanoate (4d, 80\% ee): ${ }^{1} \mathrm{H}$ NMR $\left(500 \mathrm{MHz}, \mathrm{CDCl}_{3}\right) \delta 4.14(\mathrm{q}, J=7.3 \mathrm{~Hz}, 2 \mathrm{H})$, 3.94-3.80 (m, 2H), $2.58(\mathrm{~s}, 1 \mathrm{H}), 2.44-2.34(\mathrm{~m}, 2 \mathrm{H}), 2.28-2.07$ (m, 2H), 1.95-1.86 (m, 2H), $1.26(\mathrm{t}, J=7.3 \mathrm{~Hz}, 3 \mathrm{H}) ;{ }^{13} \mathrm{C}$ NMR $\left(125 \mathrm{MHz} \mathrm{CDCl}_{3}\right) \delta 173.1,115.4(\mathrm{~d}, J=246.5 \mathrm{~Hz}), 68.1(\mathrm{~d}, J$ $=26.5 \mathrm{~Hz}), 60.6,37.4(\mathrm{~d}, J=22.8 \mathrm{~Hz}), 33.3,18.9(\mathrm{~d}, J=4.8$
$\mathrm{Hz}), 14.2 ;{ }^{19} \mathrm{~F} \mathrm{NMR}\left(470 \mathrm{MHz}, \mathrm{CDCl}_{3}\right) \delta-114.0(\mathrm{~m}) ;[\alpha]_{\mathrm{D}}{ }^{13}=$ -1.48 (c 1.1, $\mathrm{CHCl}_{3}$ ); anal calcd (\%) for $\mathrm{C}_{8} \mathrm{H}_{14} \mathrm{ClFO}_{3}: \mathrm{C}$, 45.19; H, 6.64; found: $\mathrm{C}, 44.65 ; \mathrm{H}, 6.67$. The enantiopurity was determined after conversion into the corresponding 2-naphthoate $15 \mathbf{d}$ by a procedure similar to that employed for the synthesis of 15c. The crude mixture was purified by silica gel column chromatography (hexane/EtOAc $=10: 1)$ to give $81 \%$ yield of 15d.

2-Chloro-6-ethoxy-2-fluoro-6-oxohexyl 2-naphthoate (15d, 80\% ee): ${ }^{1} \mathrm{H}$ NMR $\left(500 \mathrm{MHz}, \mathrm{CDCl}_{3}\right) \delta 8.65(\mathrm{~s}, 1 \mathrm{H}), 8.07(\mathrm{~d}, J$ $=8.8 \mathrm{~Hz}, 1 \mathrm{H}), 7.99(\mathrm{~d}, J=8.0 \mathrm{~Hz}, 1 \mathrm{H}), 7.92-7.89(\mathrm{~m}, 2 \mathrm{H})$, $7.64-7.55(\mathrm{~m}, 2 \mathrm{H}), 4.79-4.66(\mathrm{~m}, 2 \mathrm{H}), 4.13(\mathrm{q}, J=7.0 \mathrm{~Hz}, 2 \mathrm{H})$, $2.48-2.38(\mathrm{~m}, 2 \mathrm{H}), 2.37-2.17(\mathrm{~m}, 2 \mathrm{H}), 2.09-1.95(\mathrm{~m}, 2 \mathrm{H}), 1.24$ $(\mathrm{t}, J=7.0 \mathrm{~Hz}, 3 \mathrm{H}) ;{ }^{13} \mathrm{C} \mathrm{NMR}\left(125 \mathrm{MHz}, \mathrm{CDCl}_{3}\right) \delta 172.7$, 165.6, 135.7, 132.4, 131.6, 129.5, 128.6, 128.4, 127.8, 126.8, $126.2,125.1,112.5(\mathrm{~d}, J=247.6 \mathrm{~Hz}), 67.9(\mathrm{~d}, J=27.6 \mathrm{~Hz})$, $60.5,38.4(\mathrm{~d}, J=22.8 \mathrm{~Hz}), 33.4,18.9(\mathrm{~d}, J=4.8 \mathrm{~Hz}), 14.2$; ${ }^{19} \mathrm{~F}$ NMR $\left(470 \mathrm{MHz}, \mathrm{CDCl}_{3}\right) \delta-111.8(\mathrm{~m}) ;[\alpha]_{\mathrm{D}}{ }^{21}=+7.1(\mathrm{c}$ $0.31, \mathrm{CHCl}_{3}$ ); anal calcd (\%) for $\mathrm{C}_{19} \mathrm{H}_{20} \mathrm{ClFO}_{4}: \mathrm{C}, 62.21 ; \mathrm{H}$, 5.50; found: $\mathrm{C}, 62.92 ; \mathrm{H}, 6.07$. The enantiopurity was determined by HPLC (50:1 hexane/2-propanol; $1.0 \mathrm{~mL} / \mathrm{min}$; using a CHIRALPAK IB-3 column $(0.46 \mathrm{~cm} \varnothing \times 25 \mathrm{~cm})): 19.5 \mathrm{~min}$ (minor) and $24.9 \mathrm{~min}$ (major).

2-Chloro-2-cyclohexyl-2-fluoroethan-1-ol (4e, 96\% ee): ${ }^{1} \mathrm{H}$ NMR (500 MHz, $\left.\mathrm{CDCl}_{3}\right) \delta 4.02-3.83(\mathrm{~m}, 2 \mathrm{H}), 2.19-2.08$ $(\mathrm{m}, 1 \mathrm{H}), 1.98-1.92(\mathrm{~m}, 1 \mathrm{H}), 1.89-1.78(\mathrm{~m}, 3 \mathrm{H}), 1.74-1.66(\mathrm{~m}$, 1H), 1.39-1.11 (m, 6H); $\left.{ }^{13} \mathrm{C} \mathrm{NMR} \mathrm{(125} \mathrm{MHz,} \mathrm{CDCl}_{3}\right) \delta 119.0$ $(\mathrm{d}, J=247 \mathrm{~Hz}), 66.8(\mathrm{~d}, J=26.4 \mathrm{~Hz}), 44.5(\mathrm{~d}, J=20.4 \mathrm{~Hz})$, $27.3(\mathrm{~d}, J=6.0 \mathrm{~Hz}), 26.1(\mathrm{~d}, J=3.6 \mathrm{~Hz}), 25.9,25.7,25.6$; ${ }^{19} \mathrm{~F}$ NMR $\left(470 \mathrm{MHz}, \mathrm{CDCl}_{3}\right) \delta-117.8(\mathrm{~m}) ;[\alpha]_{\mathrm{D}}{ }^{22}=-6.2(c$ $0.64, \mathrm{CHCl}_{3}$ ); anal calcd (\%) for $\mathrm{C}_{8} \mathrm{H}_{14} \mathrm{ClFO}$ : C, 53.19; $\mathrm{H}$, 7.81; Cl, 19.62; F, 10.52; O, 8.86; found: $\mathrm{C}, 52.52 ; \mathrm{H}, 7.88$. The enantiopurity was determined after conversion into the corresponding 2-naphthoate $\mathbf{1 5 e}$ by a procedure similar to that employed for the synthesis of $\mathbf{1 5 c}$. The crude mixture was purified by silica gel column chromatography (hexane/ethyl acetate $=20: 1)$ to give $81 \%$ yield of $\mathbf{1 5 e}$.

2-Chloro-2-cyclohexyl-2-fluoroethyl 2-naphthoate (15e, 96\% ee): ${ }^{1} \mathrm{H} \mathrm{NMR}\left(500 \mathrm{MHz}, \mathrm{CDCl}_{3}\right) \delta 8.65(\mathrm{~s}, 1 \mathrm{H}), 8.08(\mathrm{~d}, J=$ $10.32 \mathrm{~Hz}, 1 \mathrm{H}), 7.99$ (d, $J=8.41 \mathrm{~Hz}, 1 \mathrm{H}), 7.94-7.87(\mathrm{~m}, 2 \mathrm{H})$, $7.66-7.54$ (m, $2 \mathrm{H}), 4.75$ (br d, $J=17.5 \mathrm{~Hz}, 1 \mathrm{H}), 4.75$ (br d, $J=$ $19.0 \mathrm{~Hz}, 1 \mathrm{H}), 2.25-2.16(\mathrm{~m}, 1 \mathrm{H}), 2.09-2.00(\mathrm{~m}, 1 \mathrm{H}), 1.96-1.80$ $(\mathrm{m}, 3 \mathrm{H}), 1.76-1.66(\mathrm{~m}, 1 \mathrm{H}), 1.49-1.35(\mathrm{~m}, 1 \mathrm{H}), 1.36-1.15(\mathrm{~m}$, $4 \mathrm{H}) ;{ }^{13} \mathrm{C} \mathrm{NMR}\left(100 \mathrm{MHz}, \mathrm{CDCl}_{3}\right) \delta 165.6,135.7,132.4,131.6$, $129.5,128.6,128.4,127.8,126.8,126.5,125.2,116.0(\mathrm{~d}, J=$ $248.2 \mathrm{~Hz}), 66.7$ (d, $J=25.9 \mathrm{~Hz}), 45.4$ (d, $J=20.1 \mathrm{~Hz}), 27.4$ (d, $J=5.8 \mathrm{~Hz}), 26.1(\mathrm{~d}, J=2.8 \mathrm{~Hz}), 25.8,25.7,25.6 ;{ }^{19} \mathrm{~F}$ NMR $\left(470 \mathrm{MHz}, \mathrm{CDCl}_{3}\right) \delta-114.3(\mathrm{~m}) ;[\alpha]_{\mathrm{D}}{ }^{24}=-13.7(0.36$, 
$\mathrm{CHCl}_{3}$ ); anal calcd (\%) for $\mathrm{C}_{19} \mathrm{H}_{20} \mathrm{ClFO}_{2}$ : C, 68.16; H, 6.02; Cl, 10.59; F, 5.67; O, 9.56; found: C, 68.03; H, 5.98. The enantiopurity was determined by HPLC (200:1 hexane/2-propanol; $0.5 \mathrm{~mL} / \mathrm{min}$; using a CHIRALCEL OJ-H column $(0.46 \mathrm{~cm} \varnothing \times$ $25 \mathrm{~cm}$ )): $22.5 \mathrm{~min}$ (major) and $25.4 \mathrm{~min}$ (minor).

2-Chloro-2-fluoro-2-phenylethanol (4f, 90\% ee): ${ }^{1} \mathrm{H}$ NMR $\left(500 \mathrm{MHz}, \mathrm{CDCl}_{3}\right) \delta 7.59-7.53(\mathrm{~m}, 2 \mathrm{H}), 7.46-7.40(\mathrm{~m}, 3 \mathrm{H})$, 4.15-4.04 (m, 2H), $2.15(\mathrm{t}, J=7.3 \mathrm{~Hz}, 1 \mathrm{H}) ;{ }^{13} \mathrm{C}$ NMR $(125$ $\left.\mathrm{MHz}, \mathrm{CDCl}_{3}\right) \delta 137.7(\mathrm{~d}, J=22.6 \mathrm{~Hz}), 129.8,128.6,125.3(\mathrm{~d}, J$ $=7.5 \mathrm{~Hz}), 112.9(\mathrm{~d}, J=247 \mathrm{~Hz}), 70.2(\mathrm{~d}, J=26.4 \mathrm{~Hz})$; ${ }^{19} \mathrm{~F} \mathrm{NMR}\left(470 \mathrm{MHz}, \mathrm{CDCl}_{3}\right) \delta-118.2(\mathrm{t}, J=18.8 \mathrm{~Hz}) ;[\alpha]_{\mathrm{D}}=$ $-76.5\left(c 0.6, \mathrm{CHCl}_{3}\right)$. The enantiopurity was determined by HPLC (99:1 hexane/2-propanol; $1 \mathrm{~mL} / \mathrm{min}$; using a CHIRALPAK IC column $(0.46 \mathrm{~cm} \varnothing \times 25 \mathrm{~cm})): 19.1 \mathrm{~min}$ (major) and $21.1 \mathrm{~min}$ (minor).

2-Chloro-2-fluoro-3,3-dimethylbutan-1-ol (4g) and 2-Chloro-3,3-dimethylbutan-1-ol (5g): $4 \mathrm{~g}$ and $5 \mathrm{~g}$ were inseparable by column chromatography. Therefore, isolation and determination of their enantiopurity were performed after the conversion into the corresponding 2-naphthoates $\mathbf{1 5 g}$ and $\mathbf{1 6 g}$ by a procedure similar to that employed for the synthesis of $\mathbf{1 5 c}$. The crude mixture was purified by silica gel column chromatography (hexane $/ \mathrm{CH}_{2} \mathrm{Cl}_{2}=3: 1$ ) to give $87 \%$ yield of $\mathbf{1 5 g}$, along with $80 \%$ yield of $\mathbf{1 6 g}$.

2-Chloro-2-fluoro-3,3-dimethylbutyl 2-naphthoate (15g, 99\% ee): ${ }^{1} \mathrm{H}$ NMR $\left(400 \mathrm{MHz}, \mathrm{CDCl}_{3}\right) \delta 8.68(\mathrm{~s}, 1 \mathrm{H}), 8.12(\mathrm{~d}, J$ $=8.9 \mathrm{~Hz}, 1 \mathrm{H}), 7.98(\mathrm{~d}, J=8.2 \mathrm{~Hz}, 1 \mathrm{H}), 7.92-7.88(\mathrm{~m}, 2 \mathrm{H})$, 7.63-7.54 (m, 2H), 4.89-4.78 (m, 2H), $1.26(\mathrm{~s}, 9 \mathrm{H}) ;{ }^{13} \mathrm{C}$ NMR $\left(125 \mathrm{MHz}, \mathrm{CDCl}_{3}\right) \delta 166.0,135.7,132.4,131.6,129.5,128.5$, $128.3,127.8,126.7,126.6,125.2,119.1$ (d, $J=251.9 \mathrm{~Hz}), 66.0$ $(\mathrm{d}, J=25.2 \mathrm{~Hz}), 40.8(\mathrm{~d}, J=20.4 \mathrm{~Hz}), 25.5(\mathrm{~d}, J=3.6 \mathrm{~Hz})$; ${ }^{19} \mathrm{~F}$ NMR $\left(470 \mathrm{MHz}, \mathrm{CDCl}_{3}\right) \delta-120.3(\mathrm{~m}) ;[\alpha]_{\mathrm{D}}{ }^{20}=-22.5(c$ 1.4, $\mathrm{CHCl}_{3}$ ); anal calcd (\%) for $\mathrm{C}_{17} \mathrm{H}_{18} \mathrm{ClFO}_{2}: \mathrm{C}, 66.13 ; \mathrm{H}$, 5.88 ; found: $\mathrm{C}, 65.88 ; \mathrm{H}, 6.10$. The enantiopurity was determined by HPLC (200:1 hexane/2-propanol; $1.0 \mathrm{~mL} / \mathrm{min}$; using a CHIRALPAK IB-3 column $(0.46 \mathrm{~cm} \varnothing \times 25 \mathrm{~cm})): 9.7 \mathrm{~min}$ (minor) and $14.0 \mathrm{~min}$ (major).

2-Chloro-3,3-dimethylbutyl 2-naphthoate (16g, 29\% ee): ${ }^{1} \mathrm{H} \mathrm{NMR}\left(500 \mathrm{MHz}, \mathrm{CDCl}_{3}\right) \delta 8.65(\mathrm{~s}, 1 \mathrm{H}), 8.09(\mathrm{~d}, J=8.6 \mathrm{~Hz}$, $1 \mathrm{H}), 7.98(\mathrm{~d}, J=7.6 \mathrm{~Hz}, 1 \mathrm{H}), 7.91-7.89(\mathrm{~m}, 2 \mathrm{H}), 7.62-7.55$ (m, 2H), $4.81(\mathrm{dd}, J=3.1,11.9 \mathrm{~Hz}, 1 \mathrm{H}), 4.45(\mathrm{dd}, J=8.8,11.9 \mathrm{~Hz}$, $1 \mathrm{H}), 4.11(\mathrm{dd}, J=3.1,8.8 \mathrm{~Hz}, 1 \mathrm{H}), 1.16(\mathrm{~s}, 9 \mathrm{H}) ;{ }^{13} \mathrm{C} \mathrm{NMR}(125$ $\left.\mathrm{MHz}, \mathrm{CDCl}_{3}\right) \delta 166.5,135.6,132.4,131.3,129.4,128.3,128.2$, $127.7,127.0,126.7,125.2,70.1,66.4,35.2,27.0 ;[\alpha]_{\mathrm{D}}{ }^{20}=$ +16.2 ( c 1.3, $\mathrm{CHCl}_{3}$ ); anal. calcd (\%) for $\mathrm{C}_{17} \mathrm{H}_{19} \mathrm{ClO}_{2}: \mathrm{C}$, 70.22; H, 6.59; found: $\mathrm{C}, 69.92 ; \mathrm{H}, 6.88$. The enantiopurity was determined by HPLC (200:1 hexane/2-propanol; $1.0 \mathrm{~mL} / \mathrm{min}$; using a CHIRALPAK AS-H column $(0.46 \mathrm{~cm} \varnothing \times 25 \mathrm{~cm}))$ : $7.2 \mathrm{~min}$ (major) and $8.3 \mathrm{~min}$ (minor).

2-Fluoro-3-(4-isopropylphenyl)-2-methylpropan-1-ol (13, 47\% ee) [7]: ${ }^{1} \mathrm{H}$ NMR (500 MHz, $\left.\mathrm{CDCl}_{3}\right) \delta 7.16(\mathrm{~s}, 4 \mathrm{H})$, $3.61-3.56$ (m, 2H), 2.96 (br d, $J=16.5 \mathrm{~Hz}, 1 \mathrm{H}), 2.96$ (br d, $J=$ $20.5 \mathrm{~Hz}, 1 \mathrm{H}), 2.91-2.85(\mathrm{~m}, 1 \mathrm{H}), 1.82(\mathrm{br} \mathrm{s}, 1 \mathrm{H}), 1.27(\mathrm{~d}, J=$ $21.8 \mathrm{~Hz}, 3 \mathrm{H}), 1.24(\mathrm{~d}, J=6.9 \mathrm{~Hz}, 6 \mathrm{H}) ;{ }^{13} \mathrm{C} \mathrm{NMR}(125 \mathrm{MHz}$, $\left.\mathrm{CDCl}_{3}\right) \delta 147.3,133.2(\mathrm{~d}, J=4.8 \mathrm{~Hz}), 130.3,126.3,97.4(\mathrm{~d}, J=$ $170 \mathrm{~Hz}), 67.5$ (d, $J=22.8 \mathrm{~Hz}), 41.9(\mathrm{~d}, J=22.8 \mathrm{~Hz}), 33.7,24.0$, 20.9 (d, $J=22.8) ;{ }^{19} \mathrm{~F}$ NMR (470 MHz, $\left.\mathrm{CDCl}_{3}\right) \delta-154.7$ (m); $[\alpha]_{\mathrm{D}}{ }^{25}=-7.0\left(c 0.60, \mathrm{CHCl}_{3}\right)$; The enantiopurity was determined by HPLC (99:1 hexane/2-propanol; $1 \mathrm{~mL} / \mathrm{min}$; using a CHIRALCEL OJ column $(0.46 \mathrm{~cm} \varnothing \times 25 \mathrm{~cm})): 17.4 \mathrm{~min}$ (major) and $21.8 \mathrm{~min}$ (minor).

3-(4-Isopropylphenyl)-2-methylpropan-1-ol (14, 27\% ee) [22]: ${ }^{1} \mathrm{H}$ NMR $\left(500 \mathrm{MHz}, \mathrm{CDCl}_{3}\right) \delta 7.15(\mathrm{~d}, J=8.0 \mathrm{~Hz}, 2 \mathrm{H})$, $7.10(\mathrm{~d}, J=8.0 \mathrm{~Hz}, 2 \mathrm{H}), 3.54(\mathrm{dd}, 5.0,5.7 \mathrm{~Hz}, 1 \mathrm{H}), 3.47$ (dd, $J$ $=4.6,6.1 \mathrm{~Hz}, 1 \mathrm{H}), 2.88(\mathrm{~m}, 1 \mathrm{H}), 2.71(\mathrm{dd}, J=6.5,6.9 \mathrm{~Hz}, 1 \mathrm{H})$, $2.41(\mathrm{dd}, J=5.3,8.1 \mathrm{~Hz}, 1 \mathrm{H}), 1.93(\mathrm{~m}, 1 \mathrm{H}), 1.24(\mathrm{~d}, J=6.9 \mathrm{~Hz}$, $6 \mathrm{H}), 0.92(\mathrm{~d}, J=6.5 \mathrm{~Hz}, 3 \mathrm{H}) ;{ }^{13} \mathrm{C} \mathrm{NMR}\left(125 \mathrm{MHz}, \mathrm{CDCl}_{3}\right) \delta$ 146.4, 137.8, 129.0, 126.3, 67.8, 39.3, 37.8, 33.7, 24.1, 16.6; $[\alpha]_{\mathrm{D}}{ }^{25}=-2.3\left(c 0.15, \mathrm{CHCl}_{3}\right)$; The enantiopurity was determined by HPLC (99:1 hexane/2-propanol; $1 \mathrm{~mL} / \mathrm{min}$; using a CHIRALPAK IC-3 column $(0.46 \mathrm{~cm} \varnothing \times 25 \mathrm{~cm})): 17.6 \mathrm{~min}$ (minor) and 19.9 min (major).

\section{Acknowledgements}

This study was supported by the Tatematsu Foundation and a Grant-in-Aid for Scientific Research (C) (25410113) from Japan Society for the Promotion of Science.

\section{References}

1. Ojima, I., Ed. Fluorine in Medicinal Chemistry and Chemical Biology; John Wiley \& Sons: Chichester, 2009. doi:10.1002/9781444312096

2. Bégué, J.-P.; Bonnet-Delphon, D. Bioorganic and Medicinal Chemistry of Fluorine; John Wiley \& Sons: Hoboken, 2008. doi:10.1002/9780470281895

3. Marigo, M.; Fielenbach, D.; Braunton, A.; Kjærsgaard, A.; Jørgensen, K. A. Angew. Chem., Int. Ed. 2005, 44, 3703. doi:10.1002/anie.200500395

4. Beeson, T. D.; MacMillan, D. W. C. J. Am. Chem. Soc. 2005, 127, 8826. doi:10.1021/ja051805f

5. Steiner, D. D.; Mase, N.; Barbas, C. F., III. Angew. Chem., Int. Ed. 2005, 44, 3706. doi:10.1002/anie.200500571

6. Enders, D.; Hüttl, M. R. M. Synlett 2005, 991. doi:10.1055/s-2005-864813

7. Brandes, S.; Niess, B.; Bella, M.; Prieto, A.; Overgaard, J.; Jørgensen, K. A. Chem.-Eur. J. 2006, 12, 6039. doi:10.1002/chem.200600495

8. Shibatomi, K.; Yamamoto, H. Angew. Chem., Int. Ed. 2008, 47, 5796. doi:10.1002/anie.200801682 
9. Shibatomi, K.; Narayama, A.; Soga, Y.; Muto, T.; Iwasa, S. Org. Lett. 2011, 13, 2944. doi:10.1021/ol201007e

10. Shibatomi, K.; Muto, T.; Smikawa, Y.; Narayama, A.; Iwasa, S. Synlett 2009, 241. doi:10.1055/s-0028-1087675

11. Shibatomi, K.; Soga, Y.; Narayama, A.; Fujisawa, I.; Iwasa, S. J. Am. Chem. Soc. 2012, 134, 9836. doi:10.1021/ja304806j

12. Narayama, A.; Shibatomi, K.; Soga, Y.; Muto, T.; Iwasa, S. Synlett 2013, 24, 375. doi:10.1055/s-0032-1318027

13. Barton, D. H. R.; McCombie, S. W. J. Chem. Soc., Perkin Trans. 1 1975, 1574. doi:10.1039/p19750001574

14. Halland, N.; Braunton, A.; Bachmann, S.; Marigo, M.; Jørgensen, K. A J. Am. Chem. Soc. 2004, 126, 4790. doi:10.1021/ja049231m

15. Soloshonok, V. A.; Roussel, C.; Kitagawa, O.; Sorochinsky, A. E. Chem. Soc. Rev. 2012, 41, 4180. doi:10.1039/c2cs35006h

16. Han, J.; Nelson, D. J.; Sorochinsky, A. E.; Soloshonok, V. A. Curr. Org. Synth. 2011, 8, 310. doi:10.2174/157017911794697303

17. Ueki, H.; Yasumoto, M.; Soloshonok, V. A. Tetrahedron: Asymmetry 2010, 21, 1396. doi:10.1016/j.tetasy.2010.04.040

18. Soloshonok, V. A.; Ueki, H.; Yasumoto, M.; Mekala, S.; Hirschi, J. S.; Singleton, D. A. J. Am. Chem. Soc. 2007, 129, 12112. doi:10.1021/ja065603a

19. Soloshonok, V. A. Angew. Chem., Int. Ed. 2006, 45, 766 doi:10.1002/anie.200503373

20. Amatore, M.; Beeson, T. D.; Brown, S. P.; MacMillan, D. W. C. Angew. Chem., Int. Ed. 2009, 48, 5121. doi:10.1002/anie.200901855

21. Lutje Spelberg, J. H.; van Hylckama Vlieg, J. E. T.; Bosma, T.; Kellogg, R. M.; Janssen, D. B. Tetrahedron: Asymmetry 1999, 10, 2863. doi:10.1016/S0957-4166(99)00308-0

22. Rosini, G.; Paolucci, C.; Boschi, F.; Marotta, E.; Righi, P.; Tozzi, F. Green Chem. 2010, 12, 1747. doi:10.1039/c0gc00013b

\section{License and Terms}

This is an Open Access article under the terms of the Creative Commons Attribution License (http://creativecommons.org/licenses/by/2.0), which permits unrestricted use, distribution, and reproduction in any medium, provided the original work is properly cited.

The license is subject to the Beilstein Journal of Organic Chemistry terms and conditions:

(http://www.beilstein-journals.org/bjoc)

The definitive version of this article is the electronic one which can be found at: $\underline{\text { doi: } 10.3762 / \text { bjoc. } 10.30}$ 